\title{
Pelaksanaan Supervisi Bimbingan Konseling dalam Meningkatkan Keterampilan Layanan Konseling Guru BK SMA Kabupaten Rejang Lebong
}

\author{
Desty Kurniati \\ Institut Agama Islam Negeri (IAIN) Curup \\ destykurniaty58@gmail.com \\ Tina Musyofah \\ Institut Agama Islam Negeri (IAIN) Curup \\ musyofahtina@gmail.com \\ Aji Prayetno Ojil \\ Institut Agama Islam Negeri (IAIN) Curup \\ ajiprayetno0@gmail.com
}

\begin{abstract}
Abstrak
Mastery of counseling service skills for counseling teachers always needs to be done to improve the professionalism and quality of counseling guidance services in schools. One way to improve the skills of counseling teachers is through the supervision of counseling guidance. This study aims to describe the guidance and counseling teachers' understanding of the skills they have in carrying out counseling services and to describe the implementation of counseling guidance supervision activities at SMA Rejang Lebong. This research is a quantitative descriptive study. The population of this study was all high school counseling teachers in Rejang Lebong. The results showed that some of the skills often used in counseling services were questioning skills, providing support and reinforcement, listening, closing, empathy, clarification, problemsolving, focusing, and encouraging skills. While skills that are rarely or not yet mastered include focusing, paraphrasing, confrontation, opening up, and reframing skills. The results of the evaluation of the counseling guidance supervision activities showed that $80.73 \%$ of the supervisors said they had understood, mastered, and implemented several counseling service skills taught by supervisors in providing counseling services in schools, and only about $19.27 \%$
\end{abstract}


said they had not mastered and had not fully implemented the skills taught by a supervisor.

Keywords: Supervision of counseling guidance; Counseling services; Counseling guidance teacher sklills

\begin{abstract}
Abstrak
Penguasaan keterampilan layanan konseling bagi guru BK senantiasa perlu dilakukan guna untuk meningkatkan profesionalitas dan kualitas layanan bimbingan konseling di sekoalah. Salah satu cara untuk meningkatkan keterampilan guru BK tersebut adalah melalui supervisi bimbingan konseling. Penelitian ini bertujuan untuk mendiskripsikan pemahaman guru BK tentang keterampilan yang dimiliki dalam melaksanakan layanan konseling dan untuk mendiskripsikan pelaksanaan kegiatan supervisi bimbingan konseling di SMA Rejang Lebong. Penelitian ini termasuk penelitian deskripitif kuntitatif. Populasi penelitian ini adalah seluruh seluruh Guru BK SMA di Rejang Lebong. Hasil penelitian menunjukkan bahwa beberapa keterampilan yang sering digunakan dalam layanan konseling adalah, keterampilan bertanya, memberi dukungan dan pengukuhan, memdengarkan, menutup, empati, klarifikasi, pemecahan masalah, pemfokusan dan keterampilan memberi dorongan. Sementara keterampilan yang jarang atau belum dikuasai antara lain keterampilan pemfokusan, parafrase, konfrontasi, membuka diri dan keterampilan reframing. Hasil evaluasi kegiatan supervisi bimbingan konseling menunjukkan $80.73 \%$ guru pembimbing menyakatan sudah memahami, meguasai dan melaksanakan beberapa keterampilan layanan konseling yang diajarkan oleh supervisor dalam memberikan layanan konseling di sekolah, dan hanya sekitar $19,27 \%$ yang menyakan kurang menguasai dan belum sepenuhnya melaksanaka keterampilan yang diajarkan oleh supervisor.
\end{abstract}

Kata Kunci: Supervisi Bimbingan Konseling, Layanan Konseling, Keterampilan Guru Bimbingan Konseling.

\title{
Pendahuluan
}

Guru Bimbingan Konseling (BK) adalah seorang guru yang bertugas memberikan bantuan psikologis dan kemanusiaan secara ilmiah dan professional oleh karena itu, guru bimbingan konseling harus mampu menciptakan komunikasi yang baik dalam membantu mengentaskan masalah dan mengembangkan segala potensi yang dimikiki oleh peserta didik. Guru BK yang baik adalah guru BK yang mampu bertugas secara profesional yaitu memang 
benar-benar telah dipersiapkan serta dididik secara khusus untuk menguasai segala sesuatu yang berhubungan dengan bimbingan dan konseling baik dalam pengetahuan, pengalaman, dan pribadinya dalam bimbingan dan konseling. ${ }^{1}$

Layanan konseling harus terus dilakukan pihak-pihak yang terlibat secara langsung dengan pengembangan bidang pekerjaan ini. Saat ini pekerjaan konseling sudah dapat dikategorikan sebagai pekerjaan profesional jika mengacu pada kriteria sebuah pekerjaan profesional. guru bimbingan konseling merupakan tenaga pendidik professional dalam bidang bimbingan dan konseling dengan tugas melaksanakan layanan bimbingan dan konseling yaitu mendidik, membimbing, dan mengembangkan kemampuan peserta didik dalam memecahkan permasalahan yang dialami dan segala potensi melalui layananlayanan bimbingan dan konseling. ${ }^{2}$ Pelayanan bimbingan dan konseling dapat berjalan secara efektif dan efisien dengan adanya program yang dibuat oleh guru BK. Dengan adanya program bimbingan dan konseling maka kegiatan yang dilakukan oleh guru BK akan terarah. Oleh karena pentingnya adanya program bimbingan dan konseling, seorang guru BK harus mampu merancang program bimbingan dan konseling.

Guru bimbingan konseling dalam Undang-undang No 20 Tahun 2003 Pasal 1 Ayat 6 keberadaan konselor atau guru BK dalam Sistem Pendidikan Nasional dinyatakan sebagai salah satu kualifikasi pendidik, sejajar dengan kualifikasi guru, dosen, pamong belajar, tutor, widyaiswara, fasilitator dan instruktur. Dalam surat keputusan Bersama Mendikbud dan kepala BAKN No. 0433/P/1993 dan No. 25 Tahun 1993 tentang Petunjuk Pelaksanaan Jabatan Fungsional Guru Pembimbing dan Angka Kreditnya dijelaskan bahwa "guru pembimbing adalah guru yang mempunyai tugas, tanggung jawab dan wewenang. ${ }^{3}$

Guru BK memiliki peran yang sangat penting dalam meingkatkan kualitas pendidikan. Di antara peran pentig guru BK tersebut adalah guru BK berperan membantu siswa untuk mengembangkan segala potrensi yang dimiliki agar berkembang secara maksimal, membantu mengenal potensi siswa, merencanakan masa depan dan membantu siswa mengentaskan berbagai masalah siswa. ${ }^{4}$ Di sisi lain, guru BK juga berperan dalam menigkatkan

${ }^{1}$ Dewa Ketut Sukardi dan Nila Kusmawati, (2008), Proses Bimbingan dan Konseling di Sekolah, PT. Rineka Cipta, Jakarta, hlm. 6

${ }^{2}$ W.S. Winkel, (2006), Bimbingan dan Konseling di Institusi Pendidikan, PT. Grasindo, Jakarta, hlm. 172.

${ }^{3}$ Undang-Undang Republik Indonesia No. 20 Tahun 2003 tentang Sistem Pendidikan Nasional, Bandung: Fokusmedia.

${ }^{4}$ Marfuatun, M., \& Fajrurrijal, L. M. (2019). Peran Guru Bimbingan Dan Konseling Dalam Implementasi Program BK Di SMA Negeri Se-Lombok Timur. JKP Jurnal Konseling Pendidikan), 3(1), 20-29. 
keterampilan dan motivasi belajar siswa, ${ }^{5}$ membantu siswa dalam pemilihan jurusan ${ }^{6}$ membantu siswa dalam menyesuaikan diri di sekolah, ${ }^{7}$ mengembangkan minat dan bakat siswa, ${ }^{8}$ serta membantu mengentaskan masalah yang dihadapi oleh siswa. ${ }^{9}$ Mengingat begitu pentingnya peran guru BK di sekolah, maka perlu adanya pembinaan dan pengembangan guna untuk meningkatkan keterampikan dan profesionalitas guru BK untuk menjamin ketercapaian mutu pendidikan, khususnya pada aspek bimbingan dan konseling.

Dalam menjaga mutu pendidikan diperlukan adanya control mutu (quality Control) yang mengawasi jalanya proses dan segala komponen pendukungnya. Upaya peningkatan sumber daya manusia merupakan upaya yang terintegrasi dengan peningkatan mutu pendidikan. Pendidikan sebagai sektor yang sangat vital dalam rangka membangun sumber daya manusia yang bermutu, memerlukan perhatian yang sangat besar dari semua pihak, khususnya kepala sekolah sebagai guide dalam pelakasanaan pendidikan di sekolah. Fungsi seorang kepala sekolah secara garis besar dikenal dengan istilah Emaslim, yaitu edukator, manajer, administrator, supervisor, leader, inovator, dan motivator. Kepala sekolah sebagai supervisor harus mampu mengoordinasi program-program sekolah, kelompok-kelompok, bahan, dan laporan yang berkaitan dengan sekolah serta para guru atau konselor ${ }^{10}$

Layanan bimbingan konseling di sekolah masih banyak ditemukan berbagai masalah pada tataran praktisnya. Guru Bimbingan Konseling (BK) sebagai konselor di sekolah masih mengalami kendala dan masalah yang beragam dan dari beberapa faktor sehingga tidak banyak sekolah yang mampu menjalankan layanan BK dengan baik. Sehingga problem ini harus segera disikapi secara positif agar rasa percaya diri guru BK bertambah dalam menjalankan tugasnya, karena dalam hal ini layanan bimbingan dan konseling semangkin tumbuh dan berkembang dan guru BK perlu menyadari bahwa

${ }^{5}$ Permana, S. A. (2020). Peran Guru BK dalam Meningkatkan Keterampilan Belajar dan Motivasi Belajar Siswa. Syifaul Qulub: Jurnal Bimbingan dan Konseling Islam, 1(2), 61-69.

6 Suryani, A. I. (2020). Peran Guru Bimbingan Konseling dalam Pemiliban Jurusan di Sekolah Menengah Atas Negeri 2 Siak Hulu Kecamatan Siak. Hulu Kabupaten Kampar Provinsi Riau (Doctoral dissertation, Universitas Islam Negeri Sultan Syarif Kasim Riau).

7 Rizqiyah, M. (2017). Peranan Guru Bk Dalam Membantu Penyesuaian Diri Siswa Baru Di Smp It Abu Bakar Yogyakarta. Hisbah: Jurnal Bimbingan Konseling dan Dakwah Islam, 14(2).

${ }^{8}$ Lengkey, Y. (2020). Peran Guru Bimbingan Dan Konseling Dalam Pengembangan Minat Dan Bakat Siswa. Educouns Journal: Jurnal Pendidikan dan Bimbingan Konseling, 1(1), 1-7.

${ }^{9}$ Haq, M. D. D. U. (2019). Peran Guru BK Dalam Menangani Prilaku Membolos Siswa di MTs Nu Raudlatus Shibyan. Konseling Edukasi: Journal of Guidance and Counseling, 3(2).

10 Muhammad Kristiawan and Syarwani Ahmad, "Desain Pembelajaran Sma Plus Negeri 2 Banyuasin Iii Berbasis Karakter Di Era Masyarakat Ekonomi Asean Instit Ut Agama Islam Ma 'Arif NU ( IAIM NU ) Metro Lampung," Jurnal Kajian Ilmu Pendidikan 2, no. 2 (2017): 403-432. 
pertumbuhan dan perkembangan profesi merupakan suatu keharusan untuk kinerja dan layanan yang berkualitas ${ }^{11}$

Dalam hal ini salah satu faktor yang dapat mempengaruhi peningkatan kualitas guru BK adalah supervisi. Kepala sekolah mempunyai tugas dan tanggung jawab memajukan pengajaran dan menduduki posisi yang sangat strategis didalam upaya pencapaian keberhasilan sekolah. ${ }^{12}$ Kepala sekolah bukan hanya sebagai pemimpin tetapi juga sebagai administrator, pendidikan dan supervisor pendidikan yang turut menentukan efektivitas dan efisiensi penyelenggaraan pendidikan di sekolah, termasuk melakukan suvervisi dalam pelaksanaan layanan konseling di sekolah ${ }^{13}$ Layanan konseling merupakan layanan yang harus dikuasai guru BK dengan baik, agar menjadi guru yang profesional dan mampu melaksanakan bimbingan dan konseling di sekolah dalam membantu siswa untuk mengembangkan potensinya dan mengentaskan masalah yang dihadapinya ${ }^{14}$ Oleh karena itu, untuk menjdi guru BK diperlukan beberapa persyaratan, salah satu diantaranya adalah penguasaan keterampilan konseling. ${ }^{15}$ Sebab tanpa adanya penguasaan keterampilan ini mustahil layanan konseling akan dapat berjalan dengan efektif sesuai dengan konsep layanan yang diharapkan, jadi penguasaan keterampilan ini mutlak diperlukan.

Untuk menjadi guru BK yang profesional, guru perlu meningkatkan pengetahuan wawasan dan keterampilan dalam pelaksanaan layanan bimbingan dan konseling di sekolah. Beberapa upaya yang dapat dilakukan diantaranya melakukan pembinaan dan pengembangan secara terus menerus melalui supervisi. ${ }^{16}$ Secara umum, supervisi pada dasarnya merupakan suatu pembinaan yang dilakukan guna untuk perubahan situasi pendidikan ke arah yang lebih baik $^{17}$ Menurut Ross L supervisi adalah pelayanan kepada guru-guru yang bertujuan menghasilkan perbaikan pengajaran, pembelajaran dan kurikulum. Ross L memandang supervisi sebagai pelayanan kepada guruguru yang bertujuan

11 Widiyati noverta, "Supervise Bimbingan Dan Konseling Dalam Meningkatkan Penguasaan Keterampilan Layanan Konseling Guru BK” (2019).

12 Gaol, N. T. L., \& Siburian, P. (2018). Peran Kepala Sekolah Dalam Meningkatkan Kinerja Guru. Kelola: Jurnal Manajemen Pendidikan, 5(1), 66-73.

13 Yuliandri, J., \& Kristiawan, M. (2017). Peran Kepemimpinan Kepala Sekolah Terhadap Peningkatan Kinerja Guru. Jurnal Dosen Universitas PGRI Palembang.

${ }^{14}$ Suteja, J. (2017). Teknik Bimbingan Konseling dalam Mengembangkan Potensi Siswa di Sekolah. Holistike, 2(1), 16-27.

${ }^{15}$ Kusmaryani, R. E. (2010). Penguasaan keterampilan konseling guru pembimbing di Yogyakarta. Jurnal Kependidikan: Penelitian Inovasi Pembelajaran, 40(2).

${ }^{16}$ Gede, A. I. P. (2010). Kontribusi Supervisi Bimbingan Konseling, Iklim Kerja Sekolah dan Motivasi Kerja Terhadap Kinerja Guru Pembimbing Pada SMA Negeri Di Kabupaten Badung. Jurnal Ilmiah Pendidikan dan Pembelajaran Ganesha, 7(1), 97191.

${ }^{17}$ Mashudi, F. (2018). Panduan Praktis Evaluasi Dan Supervisi Bimbingan Konseling. DIVA PRESS. 
menghasilkan perbaikan ${ }^{18}$ Supervisi menjadi landasan utama untuk menganalisis pelaksanaan kegiatan pengawasan profesional supervisi yang dimaksud adalah supervisi pembelajaran atau instruksional supervision. Dalam kajian ini yang dimaksud dengan supervisi profesional adalah sistem pemberian bantuan yang dilaksanakan oleh supervisor untuk meningkatkan kemampuan profesional guru, sehingga guru lebih mampu dalam menghadapi dan menangani tugas pokoknya dalam mendidik ${ }^{19}$ Pendapat lain menjelaskan bahwa supervisi merupakan serangkaian kegiatan yang dilakukan untuk membantu guru BK untuk meningkatkan dan mengembangkan kemampuannya dalam melaksanakan layanan bimbingan dan konseling agar tujuan yang telah ditetapkan dapat dicapai secara efektif dan efisien. ${ }^{20}$

Terdapat dua metode penelitian dalam supervisi yang dapat dilakukan kepala sekolah. Metode tersebut dibedakan antara yang bersifat individual dan kelompok yang masing-masing mempunyai kelebihan dan kelemahan.

Metode supervisi individual; adalah pelaksanaan supervisi yang diberikan kepada konselor tertentu yang mempunyai masalah khusus dan bersifat peronrangan. Supervisor disini hanya berhadapan dengan seorang konselor yang dipandang memiliki persoalan tertentu.

Metode supervisi kelompok; adalah satu cara melaksanakan program supervisi yang ditujukan kepada dua orang atau lebih. Konselor-konselor yang diduga, sesuai dengan analisi kebutuhan, memiliki masalah kebutuhan atau kelemahan-kelemahan yang sama dikelompokkan atau dikumpulkan menjadi satu atau bersama-sama. Kemudian kepada mereka diberikan layanan supervisi sesuai dengan permasalahan atau kebutuhan yang mereka hadapi. ${ }^{21}$

Ada bermacam- macam teknik supervisi dalam upaya pembinaan kemampuan konselor, yang meliputi pertemuan staf, kunjungan supervisi, buletin, profesional, perpustakaan profesional, laboraturium kurikulum, penilaian konselor, demostrasi bimbingan, darmawisata, lokakarya, kunjungan atar kelas, bacaan profesional, survei masyarakat sekolah. ${ }^{22}$ Sedangkan, teknikteknik supervisi tersebut bisadikelompokkan menjadi dua kelompok, yaitu teknik supervisi individual dan tenik supervisi kelompok. ${ }^{23}$

${ }^{18}$ Daryanto dan Tutik Rachmawati, (2015), Supervisi Pembelajaran, Yogyakarta: Gava Media, hlm 2.

${ }^{19}$ Abrani Syauqi dkk, (2016), Supervisi Pendidikan Islam, Yogyakarta: Aswaja, hlm 342.

${ }^{20}$ Mashudi, F. (2018). Panduan Praktis Evaluasi Dan Supervisi Bimbingan Konseling. DIVA PRESS.

${ }^{21}$ Noverta, "Supervise Bimbingan Dan Konseling Dalam Meningkatkan Penguasaan Keterampilan Layanan Konseling Guru BK."

22 Afriansyah, H. (2019). Proses dan Teknik Supervisi.

${ }^{23}$ Paramudita, A. (2019). Teknik Supervisi Akademik di Sekolah Islam. Madrasa, 2(1), 16. 
Kegiatan supervisi dapat dilakukan melalui berbagai proses pemecahan masalah pengajaran untuk mengubah proses belajar mengajar menjadi kegiatan yang efektif dan efisien. Dalam pelaksanaannya, tentu saja menggunakan teknikteknik supervisi yang merupakan bagian pokok dalam pelaksanaan supervisi pendidikan, maka dari itu teknik dalam melaksanakan supervisi pendidikan diantaranya adalah "teknik perseorangan dan teknik kelompok". ${ }^{24}$ Teknik individu, yang meliputi : kunjungan kelas, observasi kelas dan percakapan pribadi dan Teknik kelompok. yang meliputi: orientasi bagi guru-guru baru rapat guru, studi kelompok antar guru, tukar menukar pengalaman, lokakarya, diskusi, seminar. ${ }^{25}$

Piet A. Sahertian dan Ida Alaida Sahertian mengemukakan tiga cara pendekatan supervisi pengajaran yaitu supervisi yang bersifat directive, collaborative dan non-directive yaitu inspeksi dan supervisi yang bercorak demokratis. Bertolak dari pendapat diatas maka model supervisi bimbingan konseling meliputi Inspeksi ( supervisi yang bersifat directive), non-directive dan collaborative (supervisi yang bersifat demokratis). ${ }^{26}$

Keputusan MENPAN nomor 111 tahun 2014, menetapkan persyaratan umum dan khusus untuk di angkat dalam jabatan pengawas sekolah. Syaratsyarat tersebut berlaku bagi pengawas BK.

Syarat umum: Pegawai negeri sipil yang memenuhi angka kriteria yang ditentukan, berkedudukan dan berpengalaman sebagai guru sekurang-kurangnya selama enam tahun berturut-turut, telah mengikuti pendidikan dan pelatihan kedinasan dibidang pengawasan sekolah dan memperoleh surat tanda tamat pendidikan, setiap unsur penilaian pelaksanaan pekerjaan sekurang-kurangnya bernilai baik dalam dua tahun terakhir dan sia setinggi-tingginya lima tahun sebelum mencapai batas usia pensiun jabatan pengawas sekolah.

Syarat khusus: Pendidikan serendah- rendahnya sarjana atau yang sederajat. berkedudukan serendah-rendahnya guru dewasa, memiliki spesialisasi atau jurusan program bimbingan dan konseling atau bimbingan dan penyuluhan, dan kepala sekolah sebagai Supervisor Pendidikan. ${ }^{27}$

Dalam bidang supervisi kepala sekolah mempunyai tugas dan bertanggung jawab memajukan pengajaran melalui peningkatan profesi guru

24 Amelisa, M., \& Suhono, S. Supervisi Bimbingan Konseling dalam Meningkatkan Penguasaan Keterampilan Layanan Konseling Guru BK. Tapis: Jurnal Penelitian Ilmiah, 2, 109127.Rizqiyah, M. (2017). Peranan Guru Bk Dalam Membantu Penyesuaian Diri Siswa Baru Di Smp It Abu Bakar Yogyakarta. Hisbah: Jurnal Bimbingan Konseling dan Dakwah Islam, 14(2).

${ }^{25}$ Farid mashudi, (2013), Panduan Evalusi \& supervisi bimbingan dan Konseling, Jogjakarta: Diva press, h. 87.

${ }^{26}$ Ibid. h. 89

${ }_{27}$ Permendikbud Nomor 111 tahun 2014 tentang Bimbingan Dan Konseling Pada Pendidikan Dasar Dan Pendidikan Menengah 
secara terus menerus. Adapun tugas kepala sekolah tersebut, sebagai berikut: Membantu guru memahami tujuan pendidikan dan apa peran sekolah dalam mencapai tujuan tersebut, membantu guru melihat secara lebih jelas dalam memahami keadaan dan kebutuhan siswanya, membentuk moral kelompok yang kuat dan mempersatukan guru dalam satu tim yang efektif, dan meningkatkan kualitas pengajaran guru baik itu dari strategi, keahlian dan alat pembelajaran. Betapa Pentingnya tujuan pendidikan, Ahmad dkk, menambahkan bahwa Pendidikan pada usia remaja menjadi momen yang penting dalam menentukan karakter seseorang setelah dewasa. Lingkungan pergaulan di sekolah maupun di rumah mempunyai peluang yang sama kuatnya dalam pengembangan karakter. ${ }^{28}$

Berbagai kajian terkait dengan supervisi bimbingan konseling sudah dikaji oleh peneliti terdahulu. Misalnya, penelitian yang dilakukan oleh Septin Anggraini yang berjudul Peran supervisi BK untuk meningkatkan profesionalisme guru BK memaparkan tentang bagaimana meningkatkan profesionalisme bimbingan dan konseling dibutuhkan pengawasan dan bimbingan dari kepala sekolah sebagai supervisor. Profesionalisme guru BK dan peran supervisi BK dalam meningkatkan profesionalisme guru BK, bertujuan untuk mendiskripsikan profesionalisme guru BK. serta peran supervisi BK dalam meningkatkan profesionalisme guru BK. Tugas kepala sekolah sebagai supervisor telah dilaksanakan oleh kepala sekolah dalam meningkatkan profesionalisme guru BK dengan menggunakan beberapa teknik, diantaranya, percakapan pribadi, diskusi kelompok, penghargaan terhadap guru, penyediaan sumber belajar yang memadai dan pendelegasian guru dalam program edukatif ( MGBK dan Seminar). Belum ada pengawas dari dinas pendidikan yang datang secara khusus untuk melakukan supervisi terhadap layanan BK dan belum ada ruangan khusus untuk pelayanan $\mathrm{BK} .^{29}$

Selanjutnya penelitian yang dilakukan oleh Carolina L. Radjah, yang berjudul Keterampilan Konseling Berbasis Metakognisi mendeskripsikan karakteristik dan metakognisi konselor Sekolah Menengah Atas. Jenis penelitian yang digunakan deskriptif dengan metode survei. Subyek penelitian adalah konselor sekolah sebanyak 166 orang. Hasil penelitian menunjukkan bahwa dalam proses konseling belum sepenuhnya menerapkan keterampilan konseling berbasis metakognisi. Hal ini mengindikasikan bahwa dalam pelaksanaan konseling, konselor belum mmemperhitungkan keefektifan keterampilan intrapersonal sebagai suatu keterampilan yang terintegrasi dalam diri konselor. ${ }^{30}$

${ }^{28}$ Kristiawan and Ahmad, "Desain Pembelajaran Sma Plus Negeri 2 Banyuasin Iii Berbasis Karakter di Era Masyarakat Ekonomi Asean Instit Ut Agama Islam Ma' Arif NU ( IAIM NU ) Metro Lampung."

29 Dhanang Suwidagdho et al., (2017), "Peran Pengawas Bk Untuk Meningkatkan Profesionalitas Guru Bimbingan Dan Konseling” 1, no. 1: 137-143.

30 Carolina Radjah, "Keterampilan Konseling Berbasis Metakognisi," Jurnal Kajian Bimbingan dan Konseling 1, no. 3 (2016): 90-94. 
Dhanang Suwidagdho, dkk juga mengelaskan tentang pentingnya dilakukan pengawasan pelaksanan bimbingan dan konseling di sekolah guna untuk meningkatkan profesionalitas guru $\mathrm{BK}$, namun kenyataannya pengawasan tersebut dilakukan oleh tenaga di luar rumpun bimbingan konseling. ${ }^{31}$

Penelitian itu bertujuan untuk mendiskripsikan beberapa keterampilan yang sudah dan yang belum dikuasai oleh guru BK, serta untuk mendiskrispkan pelaksanaan kegiatan supervisi bimbingan konseling untuk meningkatkan keterampilan guru BK dalam memberikan layanan konseling di SMA Rejang Lebong. Penelitian ini didasarkan beberapa alasan, diantaranya adalah adanya keterbatasan kemampuan dan keterampilan konseling, penggunaan keterampilan konseling disesuaikan dengan kebutuhan serta keterbatasan waktu. Alasan-alasan ini menunjukan bahwa penggunaan keterampilan konseling tampaknya masih dianggap banyak memakan waktu. Hal ini karena keterbatasan kemampuan dalam menggunakan keterampilan konseling sehingga guru bimbingan konseling cenderung menggunakan pola lama yang sudah biasa dilakukan, sehingga perkembangan keterampilan konseling terabaikan. Oleh karena itu, diperlukan dilakukan pembinaan terhadap guru BK guna meningkatkan keterampilannya dalam melaksanakan layanan konseling di sekolah. Berdasarkan pemaparan di atas adanya asumsi bahwa supervisi bimbingan konseling dilaksanakan sebagai upaya untuk meningkatkan penguasaan keterampilan konseling guru bimbingan dan konseling serta dapat meningkatkan profesionalisme guru bimbingan konseling.

Penelitian ini termasuk penelitian deskriptif kuntitatif. Penelitian ini akan mendiskripsikan tentang gejala peristiwa, pemahaman dan berbagai kegiatan secara sistematis, faktual, dan akurat. Populasi penelitian ini adalah seluruh seluruh Guru BK SMA di Rejang Lebong. maka sampel pada penelitian ini berjumlah 14 sekolah SMA yang berakreditas B di Rejang Lebong. Teknik pengumpulan data yang digunakan adalah angket. Data yang diperoleh kemudian dianalisis dengan menggunakan tehnik analisa data statistik deskriptif, dengan mengunakan tehnik presentase dengan rumus :

\section{$\mathrm{K}=\mathbf{f} / \mathrm{N} \times \mathbf{1 0 0}$}

Keterangan:

$\mathrm{P} \quad=$ tingkat persentase jawaban

$\mathrm{F} \quad=$ frekuensi jawaban

$\mathrm{N} \quad=$ jumlah sampel

31 Suwidagdho, D., Lestari, L., \& Dewi, S. P. (2017). Peran Pengawas BK untuk Meningkatkan Profesionalitas Guru Bimbingan dan Konseling. In Prosiding Seminar Bimbingan dan Konseling (Vol. 1, No. 1, pp. 137-143). 


\section{Hasil dan Pembahasan}

\section{Keterampilan guru BK SMA di Kabupaten Rejang Lebong dalam melaksanakan layanan konseling}

Berdasarkan hasil penelitian dapat diketahui bahwa guru BK yang ada di SMA Rejang Lebong ada yang sudah memahami dan melaksankan beberapa keterampilan konseling dan ada yang belum memahami serta melaksankan keterampilan konseling secara maksimal. Beberapa keterampilan yang sering digunakan dalam layanan konseling adalah, keterampilan bertanya, keterampilan memberi dukungan dan pengukuhan, keterampilan memdengarkan, keterampilan menutup, keterampilan empati, keterampilan klarifikasi, keterampilan pemecahan masalah dan keterampilan memberi dorongan. Namun berdasarkan hasil penelitian menunjukkan bahwa $70,63 \%$ subjek melaporkan bahwa keterampilan tersebut telah digunakan secara optimal di lapangan dan $29,37 \%$ menyatakan belum menggukannya secara optimal. Sementara keterampilan yang jarang atau belum dikuasai seperti keterampilan pemfokusan, keterampilan parafrase, keterampilan konfrontasi, keterampilan membuka diri, keterampilan klarifikasi, keterampilan reframing. Hasil pengolahan angket menunjukkaan bahwa 17,15\% menyatakan bahwa guru BK menggunakan keterampilan konseling secara optimal, 82,85\% menyatakan belum pernah menggunakan keterampilan konsleing tersebut dalam memberikan layanan konseling di sekolah.

Berdasarkan hasil pengolahan angket tersebut, kemudian dilakukan beberapa kegiatan supervisi bimbingan konselig terhadap guru BK tingkat SMA di Rejang Lebong. Kegiatan supervisi tersebut berutujan untuk meningkatkan kemampuan guru BK dalam memberikan layanan konsleing di sekolah. Beberapa materi yang diberikan dalam kegiatan supervisi tersebut diantaranya adalah cara melakukan need assessment, cara menyuusun program BK, beberapa teknik dan keterampilan yang harus dimiliki oleh gurtu BK, strategi pelaksanaan layanan konseling dan tata cara membuat pelaporan pelaksanaan layanan konseling.

\section{Pelaksanaan supervisi bimbingan konseling dalam meningkatkan keterampilan layanan konseling Guru BK SMA Rejang Lebong}

Kegiatan supervisi bimbingan konseling di SMA Rejang Lebong dilakukan selama 10 kali pertemuan. Berdasarkan hasil evaluasi dan analisis data diperoleh keterangan bahwa sebanyak $80.73 \%$ guru pembimbing menyatakan sudah memahami, meguasai dan melaksanakan beberapa keterampilan layanan konseling yang diajarkan oleh supervisor dalam memberikan layanan konseling di sekolah, dan hanya sekitar 19,27\% yang menyakan kurang menguasai dan belum sepenuhnya melaksanaka keterampilan yang diajarkan oleh supervisor. Beberapa keterampilan konseling yang telah dilaksanakan oleh konselor tersebut diantaranya dalah attending, keterampilan bertanya, keterampilan memberi 
dukungan dan pengukuhan, keterampilan memdengarkan, keterampilan menutup, keterampilan empati, keterampilan klarifikasi, keterampilan pemecahan masalah dan keterampilan memberi dorongan. Sementara beberapa keterampilan konsleing yang belum dilaksankaan secara maksimal diantaranya adalah keterampilan pemfokusan, keterampilan parafrase, keterampilan konfrontasi, keterampilan membuka diri, keterampilan klarifikasi, keterampilan reframing.

Di sisi lain, herdasarkan hasil penelitian diketahui bahwa, guru BK di SMA Rejang Lebong telah mampu melakukan studi kebutuhan, melakukan perencanaan, melaksanakan kegiatan sesuai yang telah direncanakan, melakukan evaluasi terhadap pelayanan yang telah dilakukan, melakukan tindak lanjut layanan, serta mampu melaporkan kegiatan yang telah dilakukan. Salah satunya seperti setiap dimulai tahun ajaran baru para guru BK melaksanakan need assessment, membuat program layanan BK setelah pelaksanaan studi kebutuhan, memprioritaskan permasalahan yang berat untuk diselesaikan terlebih dahulu, merencanakan semua bentuk layanan atau kegiatan pendukung, merancang program bersama-sama dengan guru BK lainnya, dan mengarsipkan secara rapi dan teratur semua bukti penyelenggaraan BK yang telah diselenggarakan, serta melaporkannya kepada pengawas BK. Bahwa supervisi bimbingan konseling terbukti efektif dapat meningkatkan keterampilan, pemahaman guru bimbingan konseling dan mampu dalam meningkatkan penguasaan praktek konseling. Di mana dengan diterapkannya supervisi bimbingan konseling yang dilakukan kepala sekolah dapat membantu guru bimbingan konseling untuk meningkatkan dan lebih mengembangkan skill dalam keterampilan layanan bimbingan konseling.

Berdasarkan hasil penelitian tersebut, hal ini dapat dikatakan bahwa sebagian besar guru BK SMAN di Rejang Lebong telah bekerja sesuai tanggung jawab ataupun wilayah kerjanya. Sebagaimana yang dikemukakan oleh Saondi \& Suherman yang menyatakan bahwa kinerja dapat dikatakan baik dan memuaskan apabila tujuan yang dicapai sesuai dengan standar kinerja yang ditetapkan atau wilayah kerja guru. ${ }^{32}$ Prayitno, dkk menyatakan bahwa wilayah kerja guru BK yaitu menyelenggarakan pelayanan BK untuk seluruh peserta didik yang menjadi subyek ampuan masing-masing. ${ }^{33}$

Supervisi bimbingan konseling peru diberikan kepada guru BK. Dengan adanya supervisi tersebut dapat pemahaman guru BK tantang keterampilan dalam melaksanakan layanan konseling di sekolah kususnya di SMA Rejang Lebong. Hal ini tentu akan berimplikasi terhadap kinerja guru BK. Masih ada

32 Saondi, O., \& Suherman, A. (2012) Etika Profesi Keguruan. Bandung: Refika Aditama, 2012, h.21.

33 Prayitno. (2008), Dasar- Dasar Bimbingan dan Konseling. Jakarta: Rineka Cipta, h. 145 
beberapa guru BK SMA di Rejang Lebong yang masih belum mampu melaksanakan secara maksimal hasil kegiatan supervisi, namun jumlahnya relatif sedikat, yaitu sekitar 19,23\%. Hal ini disebabkan karena beberapa hal, diantaranya belum adanya guru BK yang berlatar belakang bimbingan konseling dan belu adanya guru BK yang PNS.

Supervisi bimbingan konseling upaya untuk mendorong, mengkoordinasikan dan menuntun pertumbuhan petugas bimbingan konseling atau konselor secara berkesinambungan baik secara individual maupun kelompok agar lebih memahami dan lebih dapat bertindak secara efektif dalam melaksanakan layanan bimbingan konseling, sehingga mereka mampu mendorong pertumbuhan tiap siswa (klien) secara baik. ${ }^{34}$ Senada dengan pendapat Supardi yang menyatakan bahwa supervisi merupakan faktor ekstrinsik yang berkontribusi secara signifikan terhadap professional guru. Pernyataan tersebut menjelaskan bahwa supervisi yang bagus dapat mempengaruhi professional guru.35 Pendapat yang sama juga dikemukakan oleh Masaong yang menyatakan bahwa salah satu cara untuk meningkatkan kualitas kinerja guru dalam pembelajaran yaitu melalui supervisi. Program supervisi biasanya berisikan kegiatan yang akan dijalankan untuk memperbaiki kinerja guru dalam meningkatkan situasi pembelajaran yang menjadi tanggung jawabnya.

\section{Penutup}

Berdasarkan hasil penelitian dan analisis dapat disimpulkan secara umum bahwa dalam bidang supervisi bimbingan konseling, kepala sekolah mempunyai tugas dan bertanggung jawab memajukan pengajaran melalui peningkatan profesi guru secara terus menerus. Adapun tugas kepala sekolah tersebut, sebagai berikut: (1) Membantu guru memahami tujuan pendidikan dan apa peran sekolah dalam mencapai tujuan tersebut; (2) membantu guru melihat secara lebih jelas dalam memahami keadaan dan kebutuhan siswanya; (3) membentuk moral kelompok yang kuat dan mempersatukan guru dalam satu tim yang efektif; (4) serta meningkatkan kualitas pengajaran guru baik itu dari strategi, keahlian dan alat pembelajaran.

Hasil penelitian juga menunjukkan bahwa, sepervisi bimbingan konseling dapat meningkatkan keteramnpilan guru BK dalam melaksanakan kegiatan bimbingan konseling di sekolah. Oleh karena itu, guru BK harus responsif dengan perkembangan keterampilan teknik konseling yang ada sekarang dan hendaknya keterampilan konseling yang sudah dimiliki diimplementasikan, sehingga dapat meningkatkan kualitas layanan konseling dan proses konseling dapat terlaksana secara lebih efektif. Selanjutnya

34 Anggraini, S. (2017). Peran supervisi bk untuk meningkatkan profesionalisme guru Bk. In Prosiding Seminar Bimbingan dan Konseling (Vol. 1, No. 1, pp. 332-341).

35 Supardi. 2013. Kinerja Guru. Jakarta: Raja Grafindo Persada, hal. 8 
diharapkan kepada supervisor bimbingan konseling ini agar dapat melaksanakan tugasnya dengan baik di sekolah sehingga hal itu dapat membantu para guru BK untuk dapat lebih terampil dalam penguasaan teknik bimbingan konseling

\section{Daftar Pustaka}

Abrani Syauqi dkk, (2016), Supervisi Pendidikan Islam, Yogyakarta: Aswaja

Afriansyah, H. (2019). Proses dan Teknik Supervisi.

Amelisa, M., \& Suhono, S. Supervisi Bimbingan Konseling dalam Meningkatkan Penguasaan Keterampilan Layanan Konseling Guru BK. Tapis: Jurnal Penelitian Ilmiah, 2, 109-127.

Anggraini, S. (2017). Peran supervisi BK untuk meningkatkan profesionalisme guru BK. In Prosiding Seminar Bimbingan dan Konseling (Vol. 1, No. 1, pp. 332-341).

Carolina Radjah, (2016). “Keterampilan Konseling Berbasis Metakognisi,” Jurnal Kajian Bimbingan dan Konseling 1, no. 3: 90-94.

Daryanto dan Tutik Rachmawati, (2015), Supervisi Pembelajaran, Yogyakarta: Gava Media

Dewa Ketut Sukardi dan Nila Kusmawati, (2008), Proses Bimbingan dan Konseling di Sekolah, Jakarta: PT. Rineka Cipta.

Dhanang Suwidagdho et al., (2017), "Peran Pengawas Bk Untuk Meningkatkan Profesionalitas Guru Bimbingan Dan Konseling" 1, no. 1 (2017): $137-$ 143.

Farid mashudi, (2013), Panduan Evalusi \& supervisi bimbingan dan konseling, Jogjakarta: Diva press

Gaol, N. T. L., \& Siburian, P. (2018). Peran Kepala Sekolah Dalam Meningkatkan Kinerja Guru. Kelola: Jurnal Manajemen Pendidikan, 5(1), 66-73.

Gede, A. I. P. (2010). Kontribusi Supervisi Bimbingan Konseling, Iklim Kerja Sekolah dan Motivasi Kerja Terhadap Kinerja Guru Pembimbing Pada SMA Negeri Di Kabupaten Badung. Jurnal Ilmiah Pendidikan dan Pembelajaran Ganesha, 7(1), 97191.

Haq, M. D. D. U. (2019). Peran Guru BK dalam Menangani Prilaku Membolos Siswa Di MTs Nu Raudlatus Shibyan. Konseling Edukasi: Journal of Guidance and Counseling, 3(2).

Kristiawan and Ahmad, "Desain Pembelajaran Sma Plus Negeri 2 Banyuasin Iii Berbasis Karakter Di Era Masyarakat Ekonomi Asean Instit Ut Agama Islam Ma’ Arif NU ( IAIM NU ) Metro Lampung.” 
Kusmaryani, R. E. (2010). Penguasaan keterampilan konseling guru pembimbing di Yogyakarta. Jurnal Kependidikan: Penelitian Inovasi Pembelajaran, 40(2).

Lengkey, Y. (2020). Peran Guru Bimbingan Dan Konseling Dalam Pengembangan Minat Dan Bakat Siswa. Educouns Journal: Jurnal Pendidikan dan Bimbingan Konseling, 1(1), 1-7.

Marfuatun, M., \& Fajrurrijal, L. M. (2019). Peran Guru Bimbingan Dan Konseling Dalam Implementasi Program BK Di SMA Negeri SeLombok Timur. JKP (Jurnal Konseling Pendidikan), 3(1), 20-29.

Mashudi, F. (2018). Panduan Praktis Evaluasi Dan Supervisi Bimbingan Konseling. DIVA PRESS.

Muhammad Kristiawan and Syarwani Ahmad, (2017). "Desain Pembelajaran Sma Plus Negeri 2 Banyuasin Iii Berbasis Karakter Di Era Masyarakat Ekonomi Asean Instit Ut Agama Islam Ma' Arif NU ( IAIM NU ) Metro Lampung," Jurnal Kajian Ilmu Pendidikan 2, no. 2: 403-432.

Noverta, "Supervise Bimbingan Dan Konseling Dalam Meningkatkan Penguasaan Keterampilan Layanan Konseling Guru BK."

Paramudita, A. (2019). Teknik Supervisi Akademik di Sekolah Islam. Madrasa, 2(1), 1-6.

Permana, S. A. (2020). Peran Guru BK dalam Meningkatkan Keterampilan Belajar dan Motivasi Belajar Siswa. Syifaul Qulub: Jurnal Bimbingan dan Konseling Islam, 1(2), 61-69.

Permendikbud Nomor 111 tahun 2014 tentang Bimbingan Dan Konseling Pada Pendidikan Dasar Dan Pendidikan Menengah

Prayitno. (2008), Dasar- Dasar Bimbingan dan Konseling. Jakarta: Rineka Cipta

Rizqiyah, M. (2017). Peranan Guru Bk Dalam Membantu Penyesuaian Diri Siswa Baru Di Smp It Abu Bakar Yogyakarta. Hisbah: Jurnal Bimbingan Konseling dan Dakwah Islam, 14(2).

Saondi, O., \& Suherman, A. (2012), Etika Profesi Keguruan. Bandung: Refika Aditama

Supardi. 2013. Kinerja Guru. Jakarta: Raja Grafindo Persada

Suryani, A. I. (2020). Peran Guru Bimbingan Konseling dalam Pemilihan Jurusan di Sekolah Menengah Atas Negeri 2 Siak Hulu Kecamatan Siak Hulu Kabupaten Kampar Provinsi Riau (Doctoral dissertation, Universitas Islam Negeri Sultan Syarif Kasim Riau).

Suteja, J. (2017). Teknik Bimbingan Konseling dalam Mengembangkan Potensi Siswa di Sekolah. Holistik, 2(1), 16-27. 
Suwidagdho, D., Lestari, L., \& Dewi, S. P. (2017). Peran Pengawas BK untuk Meningkatkan Profesionalitas Guru Bimbingan dan Konseling. In Prosiding Seminar Bimbingan dan Konseling (Vol. 1, No. 1, pp. 137143).

Undang-Undang Republik Indonesia No. 20 Tahun 2003 tentang Sistem Pendidikan Nasional, Bandung: Fokusmedia

W.S. Winkel, (2006), Bimbingan dan Konseling di Institusi Pendidikan, Jakarta: PT. Grasindo.

Widiyati noverta, (2019), "Supervise Bimbingan Dan Konseling Dalam Meningkatkan Penguasaan Keterampilan Layanan Konseling Guru BK".

Yuliandri, J., \& Kristiawan, M. (2017). Peran Kepemimpinan Kepala Sekolah Terhadap Peningkatan Kinerja Guru. Jurnal Dosen Universitas PGRI Palembang. 
148 | Islamic Counseling: Jurnal Bimbingan dan Konseling Islam, Vol. 5, No. 1, 2021

Halaman ini Sengaja Dikosongkan 